Erratum

\title{
Cancer and Polluted Work Places: A Case-Control Study
}

Helge Kjuus, Arne Lislerud, Per Tore Lyngdal, Harald Omland, Olav Stave, and Sverre Langård

Int Arch Occup Environ Health (1982) 49:281-292

Table 3 on p. 284 should be deleted.

In the legend to Fig. 1 on p. 286 it should read " $\geq 10$ years in a polluted work place".

In Table 8 on p. 288 it should read correctly "Grade I, uncertain, but possible exposure".

Reference no. 8: 1973. Nos. 10 and 11: J Occup Med. 